\title{
The Role of Financial Journalists in the Expectations Channel of the Monetary Transmission Mechanism
}

\section{CAMA Working Paper 37/2020 April 2020}

\section{Monique Reid}

Department of Economics, University of Stellenbosch

\section{Pierre Siklos}

Department of Economics, Wilfrid Laurier University, Balsillie School of International

Affairs

Centre for Applied Macroeconomic Analysis, ANU

\section{Timothy Guetterman}

Graduate School of Health, Creighton University

\section{Stan Du Plessis}

Department of Economics, University of Stellenbosch

\section{Abstract}

Monetary policy relies on managing the inflation expectations of the public in order to influence prices (inflation). Relying on the South African experience we argue that most of the general public are only exposed to the communication of the South African Reserve Bank (SARB) via the media. This state of affairs is fairly typical around the globe. We explore the role and biases of the journalists in transmitting the SARB's communication to the rationally inattentive general public. Our aim is to obtain insights about the factors that influence media articles that deal with monetary policy issues. Using interviews and qualitative content analysis, we explore the extent of the journalists' knowledge about inflation and monetary policy, their views concerning the credibility of the SARB, the sources of information they use, and the constraints and incentives they face in writing the articles. 


\section{Keywords}

monetary policy; central bank communication; journalists

\section{JEL Classification}

$\mathrm{E} 52, \mathrm{E} 58$

\section{Address for correspondence:}

(E) cama.admin@anu.edu.au

ISSN 2206-0332

The Centre for Applied Macroeconomic Analysis in the Crawford School of Public Policy has been established to build strong links between professional macroeconomists. It provides a forum for quality macroeconomic research and discussion of policy issues between academia, government and the private sector.

The Crawford School of Public Policy is the Australian National University's public policy school, serving and influencing Australia, Asia and the Pacific through advanced policy research, graduate and executive education, and policy impact. 


\title{
The Role of Financial Journalists in the Expectations Channel of the Monetary Transmission Mechanism
}

\author{
Monique Reid ${ }^{1}$, Pierre Siklos ${ }^{2}$, Timothy Guetterman ${ }^{3}$ and Stan Du Plessis ${ }^{4}$
}

Preliminary draft - please do not quote

April 2020

\begin{abstract}
Monetary policy relies on managing the inflation expectations of the public in order to influence prices (inflation). Relying on the South African experience we argue that most of the general public are only exposed to the communication of the South African Reserve Bank (SARB) via the media. This state of affairs is fairly typical around the globe. We explore the role and biases of the journalists in transmitting the SARB's communication to the rationally inattentive general public. Our aim is to obtain insights about the factors that influence media articles that deal with monetary policy issues. Using interviews and qualitative content analysis, we explore the extent of the journalists' knowledge about inflation and monetary policy, their views concerning the credibility of the SARB, the sources of information they use, and the constraints and incentives they face in writing the articles.
\end{abstract}

JEL codes: E52, E58,

Keywords: monetary policy; central bank communication; journalists

\footnotetext{
${ }^{1}$ mreid@sun.ac.za, Department of Economics, University of Stellenbosch, South Africa.

${ }^{2}$ Department of Economics, Wilfrid Laurier University, Balsillie School of International Affairs, Canada, and Centre for Applied Macroeconomic Analysis (CAMA).

${ }^{3}$ Graduate School of Health, Creighton University, Omaha, United States.

${ }^{4}$ Stan Du Plessis, Department of Economics, University of Stellenbosch, South Africa.
} 


\section{Introduction}

Communication is now widely recognised as an additional monetary policy tool (Blinder (2018), Siklos (2018)), with one of the primary aims being the management of the inflation expectations of price setters in order to anchor these to an inflation objective. However, some policy makers are openly acknowledging that they lack confidence in the theory of inflation (Tarullo, 2017a) or highlighting our lack of understanding of how inflation expectations are formed (Yellen, 2016).

According to the monetary economics literature, the expectations channel of the monetary transmission mechanism is one channel through which the monetary policy makers are able to influence inflation. Some even argue that it is the most important channel (Woodford, 2005). There is also increased focus on the expectations of the public, in recognition that the expectations of financial analysts (for which we have more easily accessible, high frequency data with which economists are more comfortable) are often not the same as those of price setters.

The simplification used to represent these 'channels' is not unusual for theory or models in that a full representation of all the detail undermines clarity. The example of a map used by Mankiw and Taylor (2006) is particularly illustrative. A map of the London underground is useful because it ignores irrelevant details and provides a simplification of reality. If it did include all the realistic details, it would be overwhelming. However, theorists have to keep questioning their simplifications (assumptions) to ensure they do not omit details that are central to the research question. In the case of the expectations channel of the transmission mechanism, the label 'channels' of the transmission mechanism may in itself simplify our understanding in a way that is inappropriate - it suggests that a central banks' message flows through a passive conduit to the public (its audience).

A number of researchers have argued that that the media are likely to be the primary source of information used by the public about inflation and monetary policy (Berger, Ehrmann and Fratzscher (2011), Reid and Plessis (2011) amongst others). While this is not easily refuted, there is very limited research on the way in which the media influences the formation of inflation expectations. Generally, the media has been treated as a passive conduit (channel) of communication from the central bank to the public and discrepancies between the message of the central bank and the reports in the media are most often attributed to a lack of understanding or education about monetary policy on the part of the media. In contrast, Reid et al. (forthcoming) argue that 'news agencies expend considerable resources to gather, condense, interpret, and present information provided by central banks'.

We need to better understand the behaviour and incentives that underlie inflation in order to offer a contribution towards a workable theory of inflation (Tarullo, 2017b). We argue that journalists play an important role as active intermediaries of a central bank's communication. In this paper, we aim to explore the assessment by South African journalists of the credibility and communication of the South African Reserve Bank (SARB); the way the journalists understand inflation and monetary; the incentives and challenges journalists face in reporting on the topic; and their experience with the sources on which they rely when collecting information. South Africa was one of the earliest adopters of inflation targeting, not only among emerging markets, but worldwide. It also conducts and communicates monetary policy in a manner typical of the strategies adopted by advanced economies. Therefore, the implications of our findings go well beyond ones that apply to South Africa. After all, all central banks struggle with communicating 'over the heads' of the media.

Media reports, as the final products of the process, are a natural starting point to analyse the role of the media, but these reports are an end product of a complex interaction between journalists, the 
economists they quote, the central bank's communication, and the consumers of the media (Reid et al., forthcoming). Much remains to be explored about the behaviour of each of these actors which underlies the media product. In this paper, we focus on journalists' role in the process.

While natural language processing can be used on the media articles themselves, given that they are an outcome of a complex interaction, they do not reveal the incentives and behaviour of the journalists that produce them. Instead, we used semi-structured interviews of journalists in South Africa who report regularly on monetary policy and analyse these using qualitative textual analysis. We did attempt to use computer assisted textual analysis on the transcripts of the interviews, but the nature of the data does not enable this, because the algorithms required longer pieces of text to identify meaningful associations. The depth of the insight offered by the qualitative analysis also warranted the effort to pursue this approach. ${ }^{5}$

\section{The Role of the Journalists in the Expectations Channel of the Monetary Transmission Mechanism}

When it has been discussed in the monetary economics literature, the role of the media has typically been described as a neutral 'channel' through which the central bank's communication is being 'transmitted'. Such a characterisation of central bank communication aligns with the Hypodermic Needle theory of communication which has been challenged since the 1940s (Lazarsfeld, Berelson and Gaudet, 1948). By implication, there has been little recognition in the monetary literature that the media is a platform, where different decision makers face a complex set of incentives and the content of media reports emerge following an interactive discussion or negotiation (Reid et al., forthcoming). The message of the central bank is only one input into this process, the journalists are neither neutral nor completely unbiased, and the media is not a passive conduit for the communication of a central bank.

Previous research exploring the role of the media in influencing inflation expectations has been limited and has (to the best of the authors' knowledge) focused on the final media reports (i.e., what the media reports about inflation and monetary policy). While these are valuable, they do not reveal much about the incentives, challenges and motivations faced by journalists that influence these final media reports. They do not provide insight as to why journalists produce the reports they do.

In this paper we extend the characterisation of the media reports by Reid et al. (forthcoming) by exploring the reasons why South Africa journalists have reported the way they have about inflation and monetary policy in South Africa. While the mainstream economics' literature has not yet explicitly dealt with the incentives facing journalists that mean that they do not passively assist a central bank to transmit its message to the public, Velthuis (2015) has conducted an ethnographic study in which he too argues that the ECB typically abstracted from or ignored the role of the media when designing and discussing central bank communication:

'The instrumental role of the neutral transmitter of information, which is the role the media is allocated in the ECB's communication policy, conflicts with prevailing news rules, news frames and reward systems within journalism. The struggle between the two actors is a struggle with words, in which both journalists and central bankers want to manipulate

\footnotetext{
${ }^{5}$ Gentzkow, Kelly and Taddy (2019) explore the various facets of computer assisted text analysis.
} 
markets with their communicative utterances, albeit in different and frequently opposing ways.' (Velthuis, 2015)

A typical response to the characterisation of the media reports from economists is to suggest that journalists be further educated about monetary policy and inflation, without a critical assessment of the role of financial journalists as well as factors other than a lack of education that might result in media reports that differ substantially from the communication of the central bank.

From the field of Journalism Studies, Tambini (2010) questions the role of financial journalism in the context of the evaluating the responsibilities of these journalists for identifying risks in the banking sector in the run up to the 2007/2008 financial crisis. Tambini (2010) argues that many of the rights and privileges that financial and business journalists enjoy are a result of the social role they are believed to play. However, despite the assumption that they are playing a watchdog role, his interviews with financial journalists, mostly from the UK, reveals that many of these journalists identified their primary role as being to providing investors with relevant information. This focus on investors, who are the consumers of their product (the media reports), aligns with the view that the reports on inflation and monetary policy in South Africa have a prominent consumer focus.

In his assessment of the range of criticism directed at the UK financial and business journalists, Tambini (2010) concluded that these tend to focus on the lack of skills and resources gap. Challenges identified by journalists included the increasingly complex and specialist nature of the financial stories, and the demand for increased productivity given the pressure on resources. The 'pressures of time and resources are in danger of undermining business journalism in general' (2010: 28). A central bank which acknowledges these practical realities of the environment within which financial journalists work may be better able to communicate in a more constructive manner with this audience. Perhaps in part for this reason central banks have developed tools for dealing with the media and, in some cases (e.g., Canada), have hired former journalists to head their communications staff (e.g., see Reid and Siklos, 2019).

\section{Data collection: Semi-structured interviews of financial journalists}

Given that we want to understand the incentives and behaviours of the journalists that result in the final media articles read by the public, our source of information is the journalists who write about inflation and monetary policy in South Africa. Ten South African journalists were interviewed between April and August 2016. In this section, we discuss the sample of interviewees we selected, as well as the method we used to collect information from them.

\subsection{Selection of Sample}

In line with the conditions for ethical clearance granted for this research project, we guaranteed anonymity of the journalists interviewed (both individually and of the institution to which they were associated $)^{6}$. We will, however, provide insight into process used to select the sample of journalists.

\footnotetext{
${ }^{6}$ Ethical clearance was granted for this project (proposal number: SU-HSD-002289) by the National Health Research Ethics Committee (NHREC) registration number REC-050411-032. This committee abides by the ethical norms and principles for research, established by the Declaration of Helsinki and the Guidelines for Ethical Research: Principles Structures and Processes 2004 (Department of Health).
} 
Two important considerations influenced the selection - composition and quantity. With regards to the composition of the sample, we began by considering the list of daily and weekly newspaper publications in South Africa that appeared in the All Media and Products Survey (AMPS) of 2015 (see Table A, Appendix A). Using the SAMedia collection ${ }^{7}$ for the years 2014 and 2015, relevant print news articles were downloaded for some of the important publications from the AMPS list, in order to identify which journalists were reporting most regularly in those publications ${ }^{8}$. Beyond the traditional newspapers, we also considered the AMPS list of magazines ${ }^{9}$, and then supplemented this with names from online platform $\mathrm{s}^{10}$ and radio. Besides the AMPS lists, we also asked a few leading economists (experts in the field) to provide lists of influential journalists and these were used to check that no influential journalists were missing from our list as well as to identify the real opinion leaders amongst the list we had. This approach, the informants' rating method, is an approach to identifying opinion leaders that is recognised with the opinion leadership literature (Weimann, 1994).

Of the 16 journalists we invited to participate in the 30-45 minutes interviews, 10 agreed to participate ${ }^{11}$, and we were satisfied that this sample included many of the most influential journalists as well as representatives from most the leading online and newspaper outlets. Radio was not represented as the journalists we invited declined.

With regard to the quantity of journalists interviewed, a sample of 10 interviews is not large, but the population of journalists who report on inflation and monetary policy is also small. In the appendix, we show that the number of independent newspapers with a readership of greater than $0,7 \%$ of the adult population (Table B, Appendix A). This sample of 10 interviews is small and the population is difficult to identify with certainty so we cannot draw generalisable conclusions from our data. But given our assessment of the size of the population, we can cautiously claim that this sample represents a sizable proportion of the journalists writing regularly on these topics in South Africa (representing a fair proportion of the opinion leaders ${ }^{12}$ ). Therefore, we are able to make a limited number of statements about the frequency or intensity with which certain issues are raised.

\subsection{Semi-structured interviews}

To collect information from the journalists, 10 semi-structured interviews were used. Semi-structured interviews typically comprise a set of open-ended questions that aim to encourage the interviewees to speak about a set of issues - form a narrative. Adopting a conversational approach to questioning aims to encourage the interviewee to create a narrative about each issue with limited leading by the interviewer (Adams, 2015). Moreover, the interviewer has freedom to probe and ask follow-up questions about the topic ('how' and 'why' follow up questions are often used to deepen the narrative).

Disadvantages of semi-structured interviews include that the exact questioning by interviewers can differ across participants, and they rely on the participants' abilities to formulate and articulate their

\footnotetext{
${ }^{7}$ SAMedia is an electronic archive of media clippings compiled at the University of the Free State

${ }^{8}$ The names of the journalists and other commentators who wrote on the topic were collected in an excel sheet. A large set of names was identified but very few reported regularly.

${ }^{9}$ The Financial Mail selected from this list as relevant to our study.

${ }^{10}$ MoneyWeb, Reuters, Bloomberg and Independent Online are dominant as online sources of information.

${ }^{11}$ Of those that declined, most cited time pressures.

12 The opinion leadership literature does offer a range of ways to identify opinion leaders, including the sociometric method, the informants' ratings method, the self-designation method and the observation method (Weimann, 1994). However, to specify a proportion we would need to know the size of the universe which is not clear in this case.
} 
own responses to questions. However, the language participants use can provide better understanding into how they think and talk about a topic relative to researchers' preconceptions.

Semi-structured interviews were judged to be best suited to our research problem, because there is such limited literature in economics about the role of the media in the expectations channel and there is therefore no real theory about their behaviour. Semi-structured interviews avoid ignoring important opinions and beliefs of the journalists that are missed simply because the interviewer did not think to ask the relevant questions. The use of open-ended questions is more exploratory in nature and more likely to result in deeper answers. However, an interview schedule was still designed to ensure that a certain set of topics is raised in the interview, although these questions need not be used in a rigid manner.

\subsubsection{Interview schedule design}

In designing the interviews, we began by identifying a set of themes we wished to explore with the interviewees ${ }^{13}$. These consisted of the sources of information used by journalists; monetary policy, inflation and economy; central bank communication, and the journalists' perceptions of the SARB and its role. We then designed a set of questions that were designed to be open-ended, unintimidating and exploratory. We avoided the use of jargon, which may either lead or intimidate the journalists. The questions are deliberately broad to encourage a narrative on a topic (Foddy, 1994), rather than a brief and precise answer.

\subsubsection{Interviewer-interviewee rapport}

Holstein and Gubrium (1995) argue that all interviews are unavoidably active and collaborative, in the sense that the interview is not a neutral conduit of information from the interviewee to the interviewer. Therefore, care was taken to build a constructive rapport between the interviewers and journalists in this study. Together with the assurance of anonymity, the invitation to participate in the interviews emphasised that the purpose of the interviews was to explore the experience of journalists reporting in this field in South Africa. Although we recognise that the interviewers were two academic economists, the journalists are well informed about the topic and are generally quite used to interview interactions given their careers, so they were less likely to feel intimidated. Attention was devoted to avoiding the impression that journalists were being tested on technical subject matter.

\subsubsection{Interview transcription}

We requested permission to make an audio recording the interviews at the time of the invitation to participate. This provided a way to have the interviews to be transcribed ${ }^{14}$ to enable textual analysis. To ensure the quality of the transcriptions ${ }^{15}$, economics postgraduate students were hired to do the transcriptions, and each interview was cross

\footnotetext{
${ }^{13}$ One of the main weaknesses of unstructured interviews is the lack of fixed design, which makes it difficult to replicate findings. In the case of semi-structured interviews, an interview structure and interview schedule is planned, but the researchers can still make use of more open ended questions to encourage narrative and they can use the interview schedule flexibly, probing where necessary.

${ }^{14}$ Transcriptions were conducted in the simplest manner, with the aim to record only what was said rather than how it was said (Poland, 2001).

${ }^{15}$ Inaccuracies in the transcriptions can include questions of sentence structure, failure to use quotation marks when the interviewee is quoting someone else, omission of words, and mistaking similar words (Poland, 2001).
} 
checked by a second student to limit inaccuracies due to factors such as transcriber fatigue, clarity of speech or accents, and the desire to 'tidy up' the transcriptions (Poland, 2001).

These transcriptions of the interviews represent the data that was then analysed using thematic text analysis. This analysis enabled the systematic identification of the breadth of concepts raised by the journalists, as well as in depth insight into how journalists understood and experienced these.

\section{Data analysis: Thematic text analysis}

Thematic text analysis (Kuckartz, 2014) was conducted on the 10 interviews. Through an iterative process between the economists and social methodologists on the team, we inductively developed a list of themes and codes that were used in the textual analysis (listed in Table 1).

Table 1: Themes and codes

\begin{tabular}{|c|c|}
\hline Themes & Codes \\
\hline \multirow{3}{*}{ SARB credibility } & Bank Image \\
\hline & Successes \\
\hline & Failures \\
\hline \multirow[t]{2}{*}{ SARB Communication } & Changes \\
\hline & Weaknesses \\
\hline \multirow{8}{*}{ Monetary Policy } & Economic Growth \\
\hline & Mandate \\
\hline & Long-term vs short-term \\
\hline & Exchange rate \\
\hline & Opinion on Mandate \\
\hline & Policy implementation \\
\hline & Consumer experience \\
\hline & Economic performance \\
\hline \multirow{8}{*}{ Influences on Journalists } & Financial Language \\
\hline & Economic Knowledge \\
\hline & None \\
\hline & Attitude/Availability of sources \\
\hline & Influences - Paywalls \\
\hline & Time Pressure \\
\hline & Consumer Demand \\
\hline & Background for Readers \\
\hline \multirow{6}{*}{ Sources of Information } & Economists \\
\hline & SARB - Method of Education by Bank \\
\hline & $\begin{array}{l}\text { SARB - Method of Information Provision by the } \\
\text { SARB }\end{array}$ \\
\hline & Commercial Bank \\
\hline & Statistics South Africa (StatsSA) \\
\hline & Other Journalists \\
\hline \multirow{3}{*}{ Definitions of Inflation } & Core Inflation and Second Round Effects \\
\hline & Relative Price Movements \\
\hline & Inflation expectations \\
\hline
\end{tabular}

Codes and themes break dense text data into manageable pieces in order to examine patterns within the data. A code is a focused label for a unit of meaning that is applied to a segment of text. A theme 
is a broader pattern among a group of codes. It forms a higher-level summary and comprises the key findings of qualitative text analysis.

\section{Key Findings}

In this section, the major themes will be presented separately, identifying the codes within each theme, used to systematically collect related ideas raised by the journalists. Some of the findings will be illustrated by quotes from the data (the interviews).

\subsection{Theme 1: SARB credibility}

The first theme encompasses the journalists' views of the credibility of the SARB, which is divided into three codes - Bank image, the successes of the SARB and the failures of the SARB (Table 2).

Table 2: Theme 1: SARB credibility

\begin{tabular}{l|l|l} 
Theme & Code & Code description \\
\hline \multirow{4}{*}{$\begin{array}{l}\text { SARB } \\
\text { credibility }\end{array}$} & Bank Image & $\begin{array}{l}\text { Journalists' views of the image of the SARB and any issue } \\
\text { raised about how this image has been created or changed over } \\
\text { time }\end{array}$ \\
\cline { 2 - 3 } & Successes & Areas that the journalists viewed as the bank's strengths \\
\cline { 2 - 3 } & Failures & Areas that the journalists viewed as the bank's weaknesses \\
\hline
\end{tabular}

Bank Image: Only one journalist mentioned the SARB disliking individualism and populist movements, while others focused on the fact that the SARB was independent from any political affiliation and thus its decisions were not made with politics in mind. Several journalists mentioned that the Bank was trying to maintain a positive public image by surveying inflation expectations among the populace. One journalist mentioned that the Bank knew that it was never going to be popular, but most people believed that the Bank was making the right decisions.

Two prominent observations appeared often enough to warrant particular emphasis (or greater relative weighting). Firstly, the majority of the interviewees expressed faith in the independence of the SARB from political pressure. Secondly, the majority recognise that the SARB devotes attention to its image.

'I think the strongest thing is the perception, the continuing perception that they are independence.'

'They've retained their independence, and they've been very, very vocal about the fact that they will retain independence.'

Successes and failures: The journalists identified a list of the SARB's successes. We begin by discussing the full list, which implies that we do not make any initial statements about the frequency with which these successes were raised by individuals within the group of journalists.

At least one journalist described the monetary policy decisions of the SARB as appropriate ('correct'), and favourably assesses its track record with inflation targeting. The fact that the SARB now reveals how many members of the committee voted on what side of any major policy rate decision, and publishes its own forecasts was identified as an achievement. The mandate of the SARB was described as clear, and its communication as transparent. The SARB itself was characterised as politically 
independent and internationally credible. At least one journalist also highlighted the quality of Bank regulations as a success.

However, the SARB was accused, at least once, of being too rigid on inflation targeting for an emerging economy (sometimes punishing the consumer). Some journalists wanted clearer information, and people from the Bank to be more 'accessible'. Supervision and inadequate building of reserves were also raised once as a weakness (with reference to the experience with African Bank).

Most of the failure codes were centred around increasing the policy interest rate when, in their opinion, they might not have needed to, which was viewed negatively by the public. It is interesting to note however, that two journalists also mentioned the fact that inflation had so regularly breached the top of the inflation targeting band as a failure as well. Another common code was the need for transparency in communication, although the journalists conceded that the Bank had become much better at this compared to the state of affairs 10-15 years ago. Overall, most of the journalists believed, on balance, that the SARB had been successful, as illustrated by the two quotations below:

'I think there are a very few people in the country that don't think the Reserve Bank is a world class institution that's not doing a world class job.'

'The only thing that the rating agencies have got good to say about us is that our monetary policy is unquestioned.'

\subsection{SARB Communication}

The second theme is SARB Communication, which consists of two quotes. The first captures the extent to which the journalists perceived changes in the extent and quality of the SARB's communication, and the second asks whether journalists raised any remaining weaknesses. It is worth noting that the codes are not symmetrical, in that we do not have a separate code for 'strengths', but this emerged from the process because the journalists all reported positive changes, although some journalists qualified their comments suggesting areas in which they would like to see further improvement.

Table 3: Theme 2: SARB Communication

\begin{tabular}{l|l|l} 
Theme & Code/sub-theme & Code description \\
\hline \multirow{3}{*}{$\begin{array}{l}\text { SARB } \\
\text { communication }\end{array}$} & Changes & $\begin{array}{l}\text { Changes in communication under different governors and } \\
\text { how the SARB handled these changes }\end{array}$ \\
\cline { 2 - 3 } & Weaknesses & $\begin{array}{l}\text { Journalists identified some areas where the SARB could still } \\
\text { improve its communication with the journalists }\end{array}$ \\
\hline
\end{tabular}

There were three areas for improvement that were raised more than the others. Some journalists said it would be helpful to have more information about the composition of the vote and the arguments for and against the policy decision. In line with this, some identified a need to have more information about the trajectory of the policy rate cycle and the expected effects of these decisions on the inflation outlook. Finally, some journalists argued that the SARB should speak more about the impact on the consumer of the policy decisions. The following two quotations illustrate this concern:

'but it is obvious those reasons are just a summary of why you are raising the interest rates, and without giving us also the consequences of the decision.' 
'They are not talking to the everyman when they put out those statements. So generally speaking, what people are more concerned about how much more they are going to be paying on their bonds. They could improve communication in that respect.'

Other areas for improvement identified included a lack of communication about financial stability (bubbles), and 'the impact of the rand value on inflation and the factors that influence the rand'.

\subsection{SARB Monetary Policy}

The third theme is 'Monetary Policy', which includes the eight codes listed in Table 4. These explore issues ranging from the journalists' views about the mandate of the SARB and the implementation of monetary policy, to the effects of this monetary policy on the economy and consumers.

Table 4: Theme 3: SARB Monetary Policy

\begin{tabular}{|c|c|c|}
\hline Theme & Code & Code description \\
\hline \multirow{8}{*}{$\begin{array}{l}\text { SARB } \\
\text { Monetary } \\
\text { Policy }\end{array}$} & Economic Growth & $\begin{array}{l}\text { There is a short-term trade-off between inflation and } \\
\text { economic growth when determining the appropriate level } \\
\text { of the monetary policy interest rate, which does cause } \\
\text { tension. This code identifies how journalists discuss } \\
\text { economic growth in relation to monetary policy }\end{array}$ \\
\hline & $\begin{array}{l}\text { Mandate of the } \\
\text { Bank }\end{array}$ & Mandate of the SARB. \\
\hline & $\begin{array}{l}\text { Long-term vs Short- } \\
\text { term view }\end{array}$ & $\begin{array}{l}\text { Do journalists believe that monetary policy decisions of the } \\
\text { SARB are based on present or future economic conditions? } \\
\text { Do the journalists approve of this choice by the SARB? }\end{array}$ \\
\hline & $\begin{array}{l}\text { Influence and } \\
\text { Impact of Rand }\end{array}$ & $\begin{array}{l}\text { How do journalists discuss the influence and impact of the } \\
\text { South African Rand on monetary policy? }\end{array}$ \\
\hline & $\begin{array}{ll}\text { Opinion } & \text { on } \\
\text { Mandate } & \end{array}$ & $\begin{array}{l}\text { Journalists' opinions on the appropriateness of the SARB's } \\
\text { mandate }\end{array}$ \\
\hline & $\begin{array}{l}\text { Implementation of } \\
\text { Monetary Policy }\end{array}$ & $\begin{array}{l}\text { Journalists' opinions on how well monetary policy is } \\
\text { implemented }\end{array}$ \\
\hline & $\begin{array}{l}\text { Effects of Monetary } \\
\text { Policy on consumer } \\
\text { experience }\end{array}$ & The effects of monetary policy on consumers' experience \\
\hline & $\begin{array}{l}\text { Effects of Monetary } \\
\text { Policy on economic } \\
\text { performance }\end{array}$ & The effects of monetary policy on economic performance \\
\hline
\end{tabular}

Mandate of the Bank and Opinion on the Mandate: Journalists discussed the mandate in varying degrees of detail. Some spoke about inflation management in general, while others referred to the specific numerical inflation target. Others spoke of broadening the mandate. Only one of the ten journalists interviewed seemed unclear about the SARB's mandate, and the journalists broadly supported the mandate.

Where concerns about the current mandate were discussed, the exchange rate, supply shocks or economic growth were raised. Journalists that mentioned the exchange rate, typically judged it to be a poor option to target the exchange rate, referencing past experience in South Africa. However, a few journalists did still reveal (or explicitly express) confusion about the position of the exchange rate in the inflation targeting framework. 
Journalists that did question the mandate to any degree typically argued that they would like to see greater flexibility in the mandate with respect to economic growth, but this was usually not stated in a forceful manner, as illustrated by the following quotation:

'... of course the central bank cannot cover everything, they can't fix unemployment there or everything but I think at times I think maybe their mandate is a bit narrow. That's my personal opinion.'

Economic growth and influence and impact of the Rand: These two codes denote two economic factors that attract substantial attention in South Africa, both when discussing the standard implementation of inflation targeting and when questioning the mandate of a central bank. It is interesting that only five out of the ten journalists interviewed raised economic growth when asked questions about monetary policy (including questions about the mandate of the SARB). Four of these five journalists recognised that it was hard to balance inflation and economic growth, while the fifth said that the Reserve Bank needed to broaden its mandate to pursue both equally.

Six of the ten journalists stated that they reported regularly on the exchange rate as an important factor for monetary policy, with one stating:

'In fact, it's about the only thing I consider half the time.'

Every one of these six explained that the reason the exchange rate is so important is that it has an impact on inflation itself. However, at least two of them made it clear that process through which this happens is not clear and can cause confusion.

'I think maybe the reserve bank needs to explain more of the impact of the rand value on inflation and the factors that influence the rand'

Long-term vs Short-term view: One of the main factors that differentiates the way in which the media presents the views of the SARB, the financial analysts and the consumers about inflation and monetary policy, is the differing horizons they use. The data in the current study were not conclusive about this, but there was one quotation that did illustrate that the use of different horizons does potentially undermine 'the meeting of minds' (Schelling, 1960):

'I feel they don't work on what is likely to happen or what is going to, they work on hindsight, I think, and the only thing that is forward looking for them is would be their inflation outlook, obviously.' ... 'even if you asked them how would your decision come out maybe like at the next meeting, they will say, "oh we will have to wait for developments, we would have to wait and see what happens in the US, we would have to wait and see what happens with Brexit."' 16

Effects of Monetary Policy on Economic Performance and Effects of Monetary Policy on Consumer experience: When discussing the effects on economic performance it was argued that the SARB does not have direct control over inflation, but rather influences it. The need for policy certainty and support from the fiscal authorities was also raised, as illustrated by the following quotation:

'There is no point giving the bank a mandate which the government then undermines.'

\footnotetext{
${ }^{16}$ Two relevant sections from this text were quoted here, with an ellipsis to reflect that it was shortened by removing text in the center.
} 
When the effects on consumer experience were discussed, it was argued that it affects everything from consumers' pockets to investments by companies' and the impact on consumer debt was emphasised, with reference to the level of debt of South African society as a justification for this.

'....we know that South Africa is a highly indebted nation. So it is very important for us to let the people know that if you have a home loan, if you have a store account on credit, or if you are buying anything on credit really, that this is how the interest rate decision affects you.'

\subsection{Sources of Information}

The fourth theme identified is sources of information. The journalists were asked to identify sources of information they used to write their articles, initially, without being prompted about any of them. These sources identified form the codes (Table 5) within this theme.

Table 5: Theme 4: Sources of information

\begin{tabular}{l|l|l} 
Theme & Code/sub-theme & Code description \\
\hline $\begin{array}{l}\text { Sources of } \\
\text { information }\end{array}$ & Economists & $\begin{array}{l}\text { To what extent did journalists rely on economists as a } \\
\text { source of information? }\end{array}$ \\
\cline { 2 - 3 } & $\begin{array}{l}\text { SARB - Method of } \\
\text { Education by Bank }\end{array}$ & $\begin{array}{l}\text { Journalists views on how the SARB does, or should, help } \\
\text { journalists understand monetary policy? }\end{array}$ \\
\cline { 2 - 3 } & $\begin{array}{l}\text { SARB - Method of } \\
\text { Information Provision } \\
\text { by the SARB }\end{array}$ & $\begin{array}{l}\text { Journalists' opinions about the present methods by with } \\
\text { the SARB provides financial information to journalists, } \\
\text { analysts, and consumers }\end{array}$ \\
\cline { 2 - 3 } & Commercial Bank & $\begin{array}{l}\text { To what extent did journalists rely on commercial banks } \\
\text { as a source of information? }\end{array}$ \\
\cline { 2 - 3 } & StatsSA & $\begin{array}{l}\text { To what extent did journalists rely on StatsSA as a source } \\
\text { of information? }\end{array}$ \\
\cline { 2 - 3 } & Other Journalists & $\begin{array}{l}\text { To what extent did journalists rely on other journalists } \\
\text { as sources of information? }\end{array}$ \\
\hline
\end{tabular}

Within this theme, professional economists (also often captured by the code commercial banks) and the SARB itself were mentioned most frequently, followed by other journalists (the wire services Bloomberg and Reuters were most often mentioned).

The SARB was identified by many of the journalists as the first source of information, with specific mention of the press conference where the policy decision is announced (and possible informal discussions with governors thereafter), monetary policy forums, and the monetary policy review (with specific mention of the forecasts and fan charts). A distinction was made by some of the journalists between the SARB's role in providing information and its role in educating the journalists and the public, as illustrated by the following quotation:

'...the Bank has got an educational role to play. It has to constantly explain itself, it has to constantly defend itself against criticism, and it is quite up to the challenge and it's still is going to be criticized, it's never going to be popular and it's well aware of that.'

Professional economists (many of the most respected employed at the commercial banks) were said to be helpful because they provided detailed analysis (including forecasts), often considering the 
broader economy. They were also said to offer a variety of views ${ }^{17}$ and foci that add depth, and to be accessible. One journalist expressed that the economists that are readily available are used more due to the time pressures that journalists face.

'Well it will generally be the economists that are readily available because as a journalist you try to get something out quickly...'

StatsSA was also mentioned as a good source of data and analysis that is accessible, as were the IMF, London based investment Banks, the National Credit Regulator, South African Chamber of Commerce and Industry, and the Bureau for Economic Research.

\subsection{Influences journalists face}

Under this theme, we explored influences that journalists face when writing new reports. These range from obstacles that limit the journalists' ability to use their sources efficiently to the influence of consumer demand (need to sell newspapers).

Table 6: Theme 5: Influences journalists face

\begin{tabular}{|c|c|c|}
\hline Theme & Code/sub-theme & Code description \\
\hline \multirow{8}{*}{$\begin{array}{l}\text { Influences } \\
\text { Journalists } \\
\text { face when } \\
\text { trying to make } \\
\text { use of their } \\
\text { sources to } \\
\text { write a news } \\
\text { article }\end{array}$} & Financial Language & $\begin{array}{l}\text { Opinion on the use of complex financial jargon while } \\
\text { publishing articles in newspapers, as well as the use of } \\
\text { financial language in communication by the SARB. This code } \\
\text { was meant to encompass the instances where journalists } \\
\text { mentioned financial language as a barrier. }\end{array}$ \\
\hline & $\begin{array}{l}\text { Economic } \\
\text { Knowledge }\end{array}$ & $\begin{array}{l}\text { To what extent does economic knowledge influence the } \\
\text { journalists' ability to use their sources? }\end{array}$ \\
\hline & None & $\begin{array}{l}\text { Some journalists did not mention anything significantly } \\
\text { affecting their ability to use their sources of information }\end{array}$ \\
\hline & $\begin{array}{l}\text { Attitude/Availability } \\
\text { of sources }\end{array}$ & $\begin{array}{l}\text { Some sources were viewed as inaccessible or unwilling to } \\
\text { share information }\end{array}$ \\
\hline & Paywalls & $\begin{array}{l}\text { Some sources of information are behind paywalls, which } \\
\text { could mean that journalists have to search for free } \\
\text { information }\end{array}$ \\
\hline & Time Pressure & $\begin{array}{l}\text { To what extent does time pressure affect a journalist's } \\
\text { work? }\end{array}$ \\
\hline & Consumer Demand & $\begin{array}{l}\text { To what extent to readers reflect a demand for journalists } \\
\text { to write about inflation and monetary policy? }\end{array}$ \\
\hline & $\begin{array}{l}\text { Background } \\
\text { Readers }\end{array}$ & $\begin{array}{l}\text { What was the journalists' views about how much } \\
\text { background information they needed to provide their } \\
\text { audiences in order for them to understand financial } \\
\text { articles? }\end{array}$ \\
\hline
\end{tabular}

Financial Language, Economic Knowledge and Background for Readers: Beginning with the subject matter itself, at least one journalist argued that because of the financial language, financial journalism could never have mass appeal. Some journalists even acknowledged that many journalists themselves do not understand the language the Bank is using, as illustrated by the following quotations:

'when you begin to read the more academic stuff about Monetary Policy and the international stuff certainly you would need to have the economic knowledge to make sense of it. But I

\footnotetext{
${ }^{17}$ Some journalists stated that they actively sought this in order to offer a balanced perspective.
} 
don't remember there being too many journalists in this country interested in Monetary Policy at that level at all. In fact, very few of them are.'

'Often you find journalists use terms they don't actually understand themselves but it's the term used by the Bank, and that's crazy.'

It was recommended that the Bank should try to make its language more accessible to all people, although some journalists did express that it was their role to present the communication of the SARB in more accessible language, as illustrated by the following quotation:

'And I think it is our job as journalist to turn that into understandable language for those that don't specialise in that.'

Most journalists (all except one) believed that the majority of the public required background information. Examples should include inflation trends and past monetary policy decisions. The one journalist who disagreed explained that the audience consists of mostly management, middlemanagement, and senior management. This suggest, quite naturally, that the amount of background necessary was publication or audience specific.

Besides these challenges that arise from the nature of monetary policy itself, there are a list of other influences that may make the task of the journalist easier or more difficult. These could be grouped into supply side influences (availability of sources, paywalls and time pressure) and a demand side influences (consumer demand).

Attitude/Availability of sources: The availability and willingness of sources to provide comment to the media was identified by about half the journalists in our sample as one of the primary influences on their ability to perform their job. Of the several different sources mentioned, only the members of the SARB were directly criticized for not being accessible - for the others, the journalists said that the amount of information they could get depended on the mood or personality of the source.

'... obviously the main influence is the attitude of the primary source, the Governor or the finance minister or the director general of treasury. So, if they are in an open season, if they are in a mood to encourage greater access, things will be easier.'

Paywalls and Time Pressure: Only one journalist expressed frustration that paywalls could inhibit journalists 'if you want to do a nice data journalism story'. Time pressure on the other hand was mentioned often (sometimes in combination with the availability of comment from sources).

'When you have to do things quickly, time is your biggest constraint. And I think that's the case for most other journalists.'

'It's huge. I mean if you look at the number and if you see to how it's being reduced and reduced and reduced.' ... 'I understand that newspapers are losing money they are losing circulation and all that kind of thing, so you've got an ever shrinking group of people, trying to churn out evermore'

Consumer Demand: The need for journalists to respond to consumer demand is clearly captured by the following quotation: 
'We are a commercial enterprise. We write for readers that buy our information. So we need to obviously listen to readers.'

Many of the journalists interviewed emphasised the demand from consumers for information that is relevant to their lives and decisions. However, some distinctions were made between different audiences, which typically differ across publications. Specifically, traders demand 'accurate figures and fast', and more financially literate audiences tend to prefer a bit more detail, whereas much of the general public are more interested in simple analyses, as illustrated in the following quotation:

'... there is also limited appetite amongst ordinary people for detailed analysis. You tend to stick to the things people understand like food price inflation and electricity price etc. and petrol price, rather than going into too much detail. If that is a limitation, we make a conscious choice to make it more accessible to people.'

With regard to what factors journalists believed was relevant to these readers, some spoke of the impact on the economy, but most emphasised that they believed their readers wanted to know about the effect of monetary policy on their disposable income, and debt financing in particular.

\subsection{Concepts of Inflation}

The final theme considers how journalists understand the concept of inflation. Given that inflation is measured by a range of proxies, these are likely to influence the manner in which inflation itself is understood. Furthermore, the journalists' understanding of the concept will also influence their views about appropriate monetary policy.

Table 7: Theme 7: Concepts of inflation

\begin{tabular}{l|l|l} 
Theme & Code/sub-theme & Code description \\
\hline \multirow{4}{*}{$\begin{array}{l}\text { Definitions of } \\
\text { Inflation }\end{array}$} & $\begin{array}{l}\text { Core Inflation and } \\
\text { Second Round } \\
\text { Effects }\end{array}$ & $\begin{array}{l}\text { Either explicit or implied definitions of inflation by } \\
\text { journalists that included mention of core inflation or second } \\
\text { round effects }\end{array}$ \\
\cline { 2 - 4 } & $\begin{array}{l}\text { Relative Price } \\
\text { Movements }\end{array}$ & $\begin{array}{l}\text { Either explicit or implied definitions of inflation by } \\
\text { journalists that focused on relative price movements }\end{array}$ \\
\cline { 2 - 3 } & $\begin{array}{l}\text { Inflation } \\
\text { expectations }\end{array}$ & $\begin{array}{l}\text { Either explicit or implied definitions of inflation by } \\
\text { journalists that included mention of inflation expectations }\end{array}$ \\
\hline
\end{tabular}

Only 2 journalists mentioned core inflation or second round effects in implicit or explicit definitions of inflation. 5 journalists mentioned future inflation in some way, but only 2 mentioned inflation expectations directly without having been prompted, which one journalist did acknowledge:

'... we don't discuss expectations enough ...'

\section{Discussion and conclusion}

The content analysis reveals that journalists in South Africa believe that the SARB pays careful attention to its image, and they have faith in its independence and international credibility. These opinions are supported by empirical evidence that the SARB has a track record of independence (Wessels, 2004), and has built a track record of matching its words with its actions (Reid and Du Plessis, 2010), which has resulted in increasing credibility over time (Coco and Viegi, 2019). In addition, the extent to which 
inflation expectations of financial market participants ${ }^{18}$ are well anchored has been favourably compared with a number of other reputable central banks across the world during the inflation targeting period (Reid, 2009).

Central bank communication was raised regularly across the interviews and across many of the interview questions, being identified as both a strength and a weakness of the SARB. There was consensus that the communication of the SARB had improved substantially, but some journalists still complained that it did not speak to the 'man in the street'.

More specifically, journalists wanted more detail about the arguments for and against policy decisions; the trajectory of the policy rate cycle and analysis of the expected impacts of these decisions on the economy; as well as the impact of the policy decisions on consumers. Interestingly, while they generally identified the SARB as their first source of information, the professional economists were said to offer more 'detailed analysis' and 'depth' about the 'broader economy', offering a 'variety of views'. With regard to accessibility, some of the professional economists even automatically send short analyses to directly to the journalists without them requesting after policy decisions or major economic occurrences. We are unable to determine whether it would be desirable for the SARB to become more like the analysts, but we do note that the analysts provide precisely that which is viewed as lacking from the SARB.

Communication about monetary policy is inherently difficult. The interviews suggest that both the public and many of the journalists themselves, had limited interest in, or understanding of, the academic details of monetary policy. With respect to the question of understanding monetary policy, Haldane (2017) argues that typical central bank publications have reading grade levels equivalent to a tertiary qualification, and Blinder predicts (2018: 569) that 'Central banks will keep trying to communicate with the general public, as they should. But for the most part, they will fail.' A number of central banks are more recently making a concerted effort to communicate with the public as well as the financial experts that they traditionally focused on ${ }^{19}$.

With respect to the question whether journalists have an interest in the details of monetary policy, it may be informative to consider the incentives facing them. Journalists face substantial time pressures and are often at the mercy of the mood and personality of the sources they turn to, and consumer demand dictates a typically greater focus on factors that are viewed as more relevant by the public. The factors identified as being most relevant to the media consumers are the impact of monetary policy on disposable income and debt, as well as the prices of food and petrol. This too is supported

\footnotetext{
${ }^{18}$ We acknowledge that there is substantial heterogeneity in the degree of anchoring of inflation expectations across different groups in the population of South Africa (Kabundi, Schaling and Some (2015); Ehlers (2019)). This is, however, the case in other countries too (Binder, 2015). The degree of anchoring of the societal groups that are not financial analysts is captured via surveys, which are difficult to compare very confidently as the survey questions often differ slightly. The asset price data used in Reid (2009) however, does allow us to compare the anchoring of the groups in society that is most informed about monetary policy.

${ }^{19}$ Evaluating the speeches of the members of the Bank of Canada's (BoC) Governing Council and the Fed's Board of Governors, Siklos, St. Amand, and Wajda (2018) found that while the complexity of the communication of the BoC and the Fed both increased over the period 1997-2017, the variation of complexity across speeches decreased. They suggest that this may reflect an effort to tailor speeches to different audiences. For example, the BoC is making a concerted effort to 'listen' to the public (using public opinion research), analyse the readability level of their own communication, and write simpler versions of their traditional communication (Poloz, 2018). In addition, they are engaging through social media and have even opened a Bank of Canada Museum as a novel way to reach the public.
} 
by other empirical findings, including (Cavallo, Cruces and Perez-Truglia(2017) and Coibion and Gorodnichenko (2015))

The findings in Reid et al. (forthocoming) that different groups use different horizons to reason about inflation and monetary policy, appears to offer the missing link. If we consider a particular monetary policy decision from a shorter-term perspective, then disposable income, debt repayments and relative prices such as food and petrol are the factors most relevant to the public. However, once we consider a longer-term perspective which the SARB emphasises, inflation ${ }^{20}$ can undermine an economy and erode purchasing power in a manner that is both substantial and sustained. These, longer term, concerns are completely consistent with consumers' fears about erosion of disposable income and rising prices. While the real value of their debt may decrease in an inflationary environment, any weakening of the economy is likely to reduce access to credit going forward.

The extent to which this focus on the shorter term demands of consumers is due to a partial understanding on the part of the journalists about what inflation is and the effects of monetary policy across both the shorter and longer term horizons, or a response to the consumer demand, is difficult to identify. It is quite reasonable to argue that consumer demand is partly responsible for some of the influences, such as time pressure, that limits the effort that journalists are able to devote to pursuing the details, suggesting it is impossible to disentangle the two.

The analysis in this paper does show that journalists' understanding of the SARB's mandate is good and very few are demanding the SARB prioritise economic growth in an unsophisticated manner. However, the fact that very few journalists made much reference to core inflation, second round effects or inflation expectations unless prompted, suggests that little of the reporting will present inflation as a process and capture the longer term horizon which is crucial to communicating the consumer relevance of monetary policy decisions.

From a policy perspective, the question usually posed is whether it is possible to improve the understanding of the public about monetary policy (Blinder, 2018). Perhaps it would be more fruitful to recognise the strategic nature of monetary policy and to ask whether there is scope to increase the meeting of minds (Schelling, 1960). On the part of a central bank, this could involve being willing to explicitly address the topics consumers wish to hear about and to provide the link between the shorter term and longer term very explicitly as background information, regularly. Some central banks have taken the step of employing an experienced journalist who would be able to consider the incentives facing the media.

\section{References}

Adams, W. (2015) 'Conducting Semi-Structured Interviews', in Wholey, J., Hatry, H., and Newcomer, K. (eds) Handbook of Practical Program Evaluation. 4th edn.

AMPS (2015) Readership Summary of AMPS June 2015.

Berger, H., Ehrmann, M. and Fratzscher, M. (2011) 'Monetary Policy in the Media', Journal of Money, Credit and Banking, 43(4), pp. 689-709.

Binder, C. . (2015) 'Whose Expectations Augment the Phillips Curve ?', Economic Letters, (214), pp. 17.

\footnotetext{
${ }^{20}$ Inflation is a process (Mohr, 2008) through which prices in general increase in a sustained manner.
} 
Blinder, B. A. S. (2018) 'Through a Crystal Ball Darkly : The Future of Monetary Policy Communication ${ }^{\dagger}$, American Economic Association Papers and Proceedings, 108, pp. 567-571.

Cavallo, A., Cruces, G. and Perez-Truglia, R. (2017) 'Inflation Expectations, Learning, and Supermarket Prices: Evidence from Survey Experiments.', American Economic Journal: Macroeconomics, 9(3), pp. 135.

Coco, A. and Viegi, N. (2019) 'The Monetary Policy of the South African Reserve Bank: Stance, Communication and Credibility'.

Coibion, O. and Gorodnichenko, Y. (2015) 'Is the Phillips Curve Alive and Well after All? Inflation Expectations and the Missing Disinflation', American Economic Journal: Macroeconomics, 7(1), pp. 197-232. doi: 10.2139/ssrn.2789901.

Ehlers, N. (2019) 'The rationality of expectations', Unpublished Manuscript for PhD thesis, Univeristy of Stellenbosch.

Foddy, W. (1994) Constructing questions for interviews and questionnaires: Theory and practice in social research. Cambridge: Cambridge University Press.

Gentzkow, M., Kelly, B. and Taddy, M. (2019) 'Text as Data ${ }^{\dagger}$ ', Journal of Economic Literature, 57(September), pp. 535-574.

Holstein, J. A. and Gubrium, J. F. (1995) Qualitative research methods. 37th edn. London: SAGE Publications, Inc.

Kabundi, A., Schaling, E. and Some, M. (2015) 'Monetary policy and heterogeneous inflation expectations in South Africa', Economic Modelling, 45(C), pp. 109-117.

Lazarsfeld, P. F., Berelson, B. and Gaudet, H. (1948) The people's choice: How the voter makes up his mind in a presidential campaign. 2nd edn. New York: Columbia University Press.

Mankiw, N. G. and Taylor, P. M. (2006) Economics. London: Thomson Learning.

Mohr, P. (2008) 'On inflation', South African Journal of Economics, 76(1), pp. 1-15. doi: 10.1111/j.18136982.2008.00158.x.

Poland, B. . (2001) 'Transcription Quality', in Gubrium, J. F. and Holstein, J. A. (eds) Handbook of Interview Research: Context and Method. London: SAGE Publications Inc., pp. 629-649.

Poloz, S. S. (2018) 'Let Me Be Clear: From Transparency to Trust and Understanding."', Speech delivered at Greater Victoria Chamber of Commerce, Victoria, BC, June 27.

Reid, M. B. (2009) 'the Sensitivity of South African Inflation', South African Journal of Economics, 77(September), pp. 414-429.

Reid, M. B., Bergman, Z., Du Plessis, S.A., Bergman, M.M., Siklos, P.L. (forthcoming) 'Inflation and monetary policy: What South African newspapers report in an era of policy transparency', Journal of Economic Issues.

Reid, M. B. and Plessis, S. A. (2011) 'Talking to the inattentive Public: How the media translates the Reserve Bank's communications', Stellenbosch Working Paper Series, pp. 1-32.

Reid, M. B. and Du Plessis, S. (2010) 'Loud and clear? Can we hear when the SARB speaks?', South African Journal of Economics, 78(3), pp. 269-286. doi: 10.1111/j.1813-6982.2010.01246.x.

Reid, M. B. and Du Plessis, S. (2011) Talking to the inattentive Public : How the media translates the Reserve Bank's communications, Economic Research Southern Africa. 
Reid, M. B. and Siklos, P. L. (2019) 'Building Credibility and Influencing Expectations: The Evolution of Central Bank Communication in Advanced and Emerging Market Economies', presented at the 2019 Biennial Conference of the South African Reserve Bank, October.

Schelling, T. C. (1960) Strategy of Conflict. Cambridge: Harvard University Press.

Siklos, P. L. (2018) 'Has Monetary Policy Changed? How the Crisis Shifted the Ground Under Central Banks', Rimini Centre for Economic Analysis. (Working Paper series 18-10).

Tambini, D. (2010) 'What are Financial Journalists for?, 11:2', Journalism Studies, 11(2), pp. 158-174.

Tarullo, D. K. (2017a) 'Monetary Policy Without a Working Theory of Inflation', pp. 1-19.

Tarullo, D. K. (2017b) 'Monetary Policy Without a Working Theory of Inflation', October 20, pp. 1-19.

Velthuis, O. (2015) 'Making monetary markets transparent: the European Central Bank's communication policy and its interactions with the media, Economy and Society 44:2, 316-340,' Economy and Society, 44(2). doi: 10.1080/03085147.2015.1013355.

Weimann, G. (1994) The Influentials: People Who Influence People. Albany: State University of New York Press.

Wessels, G. M. (2004) 'Central bank independence before and after the democratisation of South Africa', South African Journal of Economic History, 19(1-2), pp. 132-157.

Woodford, M. (2005) 'Central Bank Communication and Policy Effectiveness', in Economic Policy Symposium - Jackson Hole, Federal Reserve Bank of Kansas City, pp. 399-474.

Yellen, J. (2016) 'Macroeconomic Research After the Crisis', A speech at 'The Elusive 'Great' Recovery: Causes and Implications for Future Business Cycle Dynamics." 60th annual economic conference of the Federal Reserve Bank of Boston, Boston, Massachusetts, October 14, 2016.

\section{Appendix A: List of Newspapers}

The South Africa Audience Research Foundation (SAARF) All Media and Products Survey (AMPS) of June 2015 reported that $27,3 \%$ of the adult population in South Africa reports reading any daily newspaper and $29,4 \%$ report reading any weekly newspaper (AMPS, 2015). From the list of daily and weekly newspapers in the report that contributed to these totals, we excluded publications that were not in English or Afrikaans ${ }^{21}$ and those that would not have reported on monetary policy or inflation due to the scope of the publication ${ }^{22}$ and create the list in Table A.

The readership numbers of each publication were the first indication of which newspapers were important, with the Sunday Times standing out in this regard. However, it should be noted that two smaller publications - the Business Day and the Financial Mail (a weekly magazine) are likely to have a far larger effect on the public's views about inflation and monetary policy than their readership numbers suggest because of the nature of the publications and the audiences they attract (who are likely to be opinion leaders). Furthermore, media outlets often 'share' skills, which is reflected in the fact that the Business Report appears in the Cape Times, The Mercury, The Pretoria News and The Star. One of the journalists described how three important newspapers had recently combined their

\footnotetext{
${ }^{21}$ These were: Isolezwe; Ilanga Langesonto; Isolezwe Ngesonto; Isolezwe Ngomgoielo.

22 Soccer Laduma; Daily Sun and Son (see Reid and Du Plessis, 2011)
} 
resources to create a single newsroom. Bloomberg or Reuters journalists also often write articles that are printed in a number of the newspapers ${ }^{23}$.

Table A: Newspapers in South Africa

\begin{tabular}{l|l|l|l}
\hline Daily newspapers & $\begin{array}{l}\% \text { of adult } \\
\text { population }\end{array}$ & Weekly Newspapers & $\begin{array}{l}\% \text { of adult } \\
\text { population }\end{array}$ \\
\hline Business Day & 0,2 & City Press & 4,6 \\
Cape Argus & 0,9 & Independent on Saturday & 0,2 \\
Cape Times* & 0,6 & Mail and Guardian & 1,5 \\
Citizen & 1.1 & Post & 0,6 \\
Daily Dispatch & 0,7 & Rapport & 2,8 \\
Daily News & 0,7 & Saturday Citizen & 0,3 \\
Daily Voice & 1,1 & Saturday Dispatch & 0,3 \\
DFA & 0.2 & Saturday Star & 0,7 \\
Herald & 0,5 & Sunday Independent & 0,2 \\
Mercury* & 0,5 & Sunday Times & 9,8 \\
New Age & 0.4 & Sunday Tribune & 0,8 \\
Sowetan & 4,2 & Sunday World & 4,0 \\
The Star* & 1,6 & Weekend Argus Saturday & 0,3 \\
The Times & 0,9 & Weekend Argus Sunday & 0,4 \\
The Witness & 0.2 & Weekendpost & 0,4 \\
& & Weekend Witness & 0,2 \\
& & The Zimbabwean & 0,2 \\
\hline
\end{tabular}

Source: AMPS, 2015

Notes: 1) This list excludes a few publications that are not in English or Afrikaans or have content that is irrelevant to this research (eg focuses exclusively on soccer).

2) Publications with * contain the same Business Report supplement

3) Some of the daily publications have a weekly counterpart that is listed separately above but will have been produced by the same journalists (for example, Cape Argus, Argus on Saturday and Argus on Sunday)

In table B, we adjust the list given in Table A by combining the daily and weekly publications from the same newspaper, where the same journalists are likely to report, and we only list newspapers with readership of $>0,7 \%$ of the adult population. The choice to truncate the list at $0,7 \%$ is arbitrary, but is an attempt to show that the list shortens substantially once those with lower readership numbers is excluded. However, as discussed above, we include the Business Day and Financial Mail in the list due to their perceived impact on the people who are likely to be the opinion leaders on topics of monetary policy and inflation within society.

Given the considerations above, we conducted searches to identify journalists that had been responsible for a large proportion of the reporting on inflation and monetary policy in the list of more influential publications in 2014 and 2015. There is likely to be a relatively small number of journalists reporting on inflation and monetary policy in South Africa that have a sizable reach.

\footnotetext{
${ }^{23}$ This conclusion is supported by the journalists themselves when asked about sources of information.
} 
Table B: List of newspapers (combining daily and weekly publications)

\begin{tabular}{l|l}
$\begin{array}{l}\text { Newspaper (with readership }>0,7 \% \text { or identified as } \\
\text { highly relevant in terms of scope and audience) }\end{array}$ & Readership - daily (weekly) \\
\hline Business Day & 0,2 \\
Financial Mail (weekly Magazine) & 0,3 \\
Cape Argus & $0,9(0,3$ and 0,4$)$ \\
Business Report & $2,7^{*}$ \\
Citizen & $1.1(0,3)$ \\
Daily Voice & 1,1 \\
Sowetan & 4,2 \\
The Times & $0,9(9,8)$ \\
City Press & $(4,6)$ \\
Mail and Guardian & $(1,5)$ \\
Rapport & $(2,8)$ \\
Sunday Tribune & 0,8 \\
Sunday World & 4,0 \\
\hline
\end{tabular}

\section{Appendix B: Interview Schedule}

Journalists' experience reporting on inflation and monetary policy

\begin{tabular}{l|l|l}
\hline \multicolumn{3}{l}{ Interviewer: } \\
\hline Interviewee: & Time: & Place: \\
\hline Date: & \multicolumn{2}{c}{ Interviewer Introduction }
\end{tabular}

Purpose of study: I sincerely appreciate that you agreed to speak to me.

My team and I are interested in your opinion about your reporting on inflation and monetary policy, why this is important, and what sources you use. We would like to improve our understanding of the role played by the media and the financial analysts quoted in media reports. We are asking you to participate in the study because you are employed as a journalist in South Africa.

\begin{tabular}{l}
\hline Obtain Informed Consent \\
\hline Any questions before we begin? \\
\hline Record Session:
\end{tabular}

As we indicated in the consent form you signed, I need to make an audio recording of this interview so that I don't have to make too many notes while speaking to you.

\section{Interview Questions}

(Treat sub-questions as prompts for interviewer if interviewee does not discuss these ideas)

Further sample probes; use as-needed:

1. Can you expand on your answer/tell me more?

2. Can you explain your answer?

3. Can you give me a specific example of that?

4. Can you tell me more?

5. Can you tell me a bit more about the last time you experienced that?

6. Do you personally feel that way?

7. Is that something you have experienced? 


\section{First third of interview:}

1) Why is reporting on monetary policy important to you? (collect a list of reasons).

a. [If inflation is not mentioned, ask why reporting on inflation is important to you? If inflation is mentioned - perhaps probe a little for details]

2) Which information sources on monetary policy do you find the best? (collect a list)

a. Why do you use this/these sources?

b. What do you think about Reserve Bank communications on monetary policy?

i. In attempting to understand the decisions of the Reserve Bank, what do you perceive as being less clearly communicated?

ii. Have you noticed any changes in the communication of the Reserve Bank since the adoption of inflation targeting in 2000?

1. Would you please explain a little further/provide an example?

c. To what extent do you rely on financial analysts for insight?

i. Which financial analysts do you consult?

ii. Why do you select this person/these people?

3) You've just discussed the information sources you use when reporting on monetary policy how does this differ when you report on inflation?

a. Which sources do you find best?

b. Why do you use this/these sources?

4) What are the influences you face that affect your ability to explore various sources of information about monetary policy?

a. Do these influences differ in any way when you report on inflation?

5) What background on monetary policy do your readers expect you to repeat in each article in order for your article to be accessible to them?

\section{$\underline{\text { Rest of interview: }}$}

The next set of questions will focus on your impression of the work of the Reserve Bank

6) In what sense do you believe that the priorities given to the Reserve Bank by the Minister of Finance are appropriate or not?

7) In what areas has the Reserve Bank been successful, in your opinion? 
8) In what areas has the Reserve Bank been not so successful?

i) How would you explain these?

ii) [If they don't mention the blunt instrument argument]: How valid do you think the criticism is that monetary policy is unable to influence inflation?

9) To what extent does the Reserve Bank appear to focus more on what is likely to happen to future economic performance rather than the current unfolding of the economy?

a. - Could you perhaps give an example? [If they do not speak about expectations, try probe again at the end of the interview ie Q11]

10) [if the interviewee has not mentioned the exchange rate earlier in the interview] In your assessment, do you consider the value of the rand when assessing pressures on South Africa's inflation rate?

11) [if the interviewee has not mentioned inflation expectations]

In what sense do you believe that the Reserve Bank considers the views of the public about future inflation?

\section{Conclusion of interview:}

12) Is there anything that you can think of in relation to the questions you've answered or in relation to this project - how you report on monetary policy and what, in your opinion, your readers should know about it - that you have not said yet? [Pause of about 3 to 5 seconds to allow the interviewee to reflect on this ]

This concludes the interview. Thank you for your time. You have been most helpful. If you're interested we'll gladly share our research results with you. As we indicated in the consent form you signed, we can guarantee confidentiality of your answers and information, and confirm that we follow the protocol of the University of Stellenbosch with regards to ethics.

In the meantime, if you have any further questions about this research or this interview, you have my email address. Feel free to send me a message anytime...

\section{TURN OFF RECORDER}

